\title{
HUBUNGAN MOTIVASI BELAJAR DAN PERSEPSI SISWA TENTANG METODE PEMBELAJARAN GURU DENGAN PRESTASI BELAJAR EKONOMI SISWA KELAS XI SEMESTER I MA NURUL MUTAQIN PENUMANGAN BARU TAHUN PEMBELAJARAN 2011-2012
}

\author{
Oleh: Edi Susanto \\ (UNIVERSITAS MEGOUPAK TULANGBAWANG LAMPUNG)
} edi180275@gmail.com

\begin{abstract}
Abstrak-Penelitian ini bertujuan untuk mengetahui: (1) Hubungan Motivasi Belajar dengan Prestasi Belajar Ekonomi;(2)Hubungan Persepsi Siswa tentang Metode Pembelajaran Guru dengan Prestasi Belajar Ekonomi:(3) Hubungan Motivasi Belajar,dan Persepsi Siswa tentang Metode Pembelajaran Guru secara bersama-sama dengan Prestasi Belajar Ekonomi. Metode penelitiannya adalah Asosiatif dengan menggunakan pendekatan Ex-Post Facto dan hasil penelitian ini menunjukkan : (1) terdapat hubungan positif dan signifikan antara Motivasi Belajar dengan Prestasi Belajar Ekonomi, hal tersebut ditunjukkan dari harga $r$ hitung lebih besar dari $r$ tabel dengan $N=31$ pada taraf signifikansi $5 \%(0,886>0,355)$, (2) terdapat hubungan positif dan signifikan antara Persepsi Siswa tentang Metode Pembelajaran Guru dengan Prestasi Belajar Ekonomi, hal tersebut ditunjukkan dari harga $r$ hitung lebih besar dari $r$ tabel dengan $N=31$ pada taraf signifikansi 5\% (0,670>0,355), (3) terdapat hubungan positif dan signifikan antara Motivasi Belajar, dan Persepsi Siswa tentang Metode Pembelajaran Guru dengan Prestasi Belajar Ekonomi, hal tersebut ditunjukkan dari harga $F$ hitung 0,894 lebih besar dari harga $F$ tabel 0,355 dan besarnya koefisien korelasi ganda $(R)$ sebesar 0,894 .
\end{abstract}

Kata Kunci : Motivasi Belajar, Persepsi Siswa, Prestasi Belajar

\begin{abstract}
This research aims at finding out (1) the relationshipof learningmotivation with achievement learning economic;(2) the relationship students perception with achievement learning economic;(3)the relationship of learning motivation and students perception of the teacher learning methods together with achievment learning economic. Research methods is usedassosiatif with Ex-Post Factoapproach. Base on the result of the analysis and discussion, it can be concluded that (1) there is a positive and significant relationship between learning motivation and economic learning achievement. This is indicated by theprice $r$ count is greater than $r$ table with $N 31 \propto 5 \%(0,886>0,355)$; (2)there is a positive and significant relationship between student perception and economic learning achievement. This isindicated by the price $r$ countis greater than $r$ table with $N 31 \propto 5 \%(0,670>0,355)$; (3)there is a positive and significant relationship between Learning Motivation, and Student Perception of Teacher Learning Methods with Economic Learning Achievement, it is shown from the price of $F$ count 0.894 greater than
\end{abstract}


the price of $F$ table 0.355 and the magnitude of the multiple correlation coefficient $(R)$ of 0.894 .

Keywords: Learning motivation, students perception and achievement learning

\section{PENDAHULUAN}

Peningkatan kualitas sumber daya manusia di Indonesia terus diupayakan dan dikembangkan seiring dengan perkembangan zaman yang semakin global. Peningkatan sumber daya manusia ini juga berpengaruh terhadap dunia pendidikan. Pendidikan yang merupakan ujung tombak dalam pengembangan sumber daya manusia harus bisa berperan aktif dalam meningkatkan kualitas dan juga kuantitas. Upaya pengembangan pendidikan tersebut harus sesuai dengan proses pembelajaran yang tepat agar anak didik menerima pelajaran dengan baik.

Menurut Slameto (2003:54) faktor-faktor yang mempengaruhi prestasi belajar ada dua macam yaitu faktor internal dan faktor eksternal:

1. Faktor Internal adalah faktor yang ada dalam individu yang sedang belajar seperti:

a) Faktor Jasmaniah, meliputi : Faktor kesehatan proses belajar seseorang akan terganggu jika kesehatan orang terganggu, selain itu juga akan cepat lelah, kurang bersemangat, mudah pusing, mengantuk, kurang darah atau gangguan fungsi alat indera.

b) Cacat tubuh cacat tubuh ini dapat berupa buta, tuli, patah kaki dan patah tangan. Faktor Psikologis, meliputi : intelegensi siswa yang mempunyai tingkat intelegensi yang tinggi akan lebih berhasil daripada yang mempunyai tingkat intelegensi yang rendah. Siswa yang mempunyai intelegensi tinggi dapat berhasil dengan baik dalam belajarnya dikarenakan belajar dengan menerapkan metode belajar yangefisien. Sedangkan yang mempunyai intelegensi rendah perlu mendapatkan pendidikan khusus. Perhatian-Perhatian menurut Ghazali yang dikutip oleh Slameto (2003:55) adalah keaktifan jiwa yang dipertinggi, jiwa itu pun semata-mata tertuju kepada suatu obyek benda/hal atau sekumpulan obyek. Untuk dapat menjamin hasil belajar yang baik maka siswa harus mempunyai perhatian terhadap bahan yang dipelajarinya.

c) Minat adalah kecenderungan yang tetap untuk memperhatikan dan mengenang beberapa kegiatan. Minat besar 
pengaruhnya terhadap belajar.

Bahan pelajaran yang menarik minat siswa, lebih mudah dipelajari dan disimpan karena minat menambah kegiatan belajar.

d) Bakat adalah kemampuan untuk belajar. Kemampuan itu baru akan terealisasi menjadi kecakapan yang nyata sesudah belajar atau berlatih.

e) Motivasi seseorang akan berhasil dalam belajarnya bila mempunyai penggerak atau pendorong untuk mencapai tujuan. Penggerak atau pendorong inilah yang disebut dengan motivasi.

f) Kematangan adalah suatu tingkat atau fase dalam pertumbuhan seseorang, di mana alat-alat tubuhnya sudah siap untuk melaksanakan kecakapan baru. Belajar akan berhasil bila anak sudah siap (matang).

g) Kesiapan adalah kesediaan untuk memberikan respon atau bereaksi. Kesiapan ini perlu diperhatikan dalam proses belajar mengajar karena jikasiswa sudah memiliki kesiapan dalam belajar maka hasil belajarnya akan lebih baik. Faktor Kelelahan dibedakan menjadi dua macam yaitu kelelahan jasmani dan kelelahan rohani.
Kelelahan jasmani terlihat dengan lemah lunglai, sedangkan kelelahan rohani terlihat dengan kelesuan dan kebosanan.

2. Faktor Eksternal.

a) Keadaan keluarga merupakan lingkungan utama dalam proses belajar. Keadaan yangada dalam keluarga mempunyai pengaruh yang besar dalam pencapaian prestasi belajar misalnya cara orang tua mendidik, relasi anggota keluarga, suasana rumah,keadaan ekonomi keluarga, pengertian orang tua.

b) Keadaan sekolah adalah lingkungan di mana siswa belajar secara sistematis. Kondisi ini meliputi metode mengajar, kurikulum, relasi guru dengan siswa, relasi siswa dengan siswa, disiplin sekolah, alat pelajaran, metode belajar dan fasilitas yang mendukung lainnya.

c) Keadaan masyarakat siswa akan mudah kena pengaruh lingkungan masyarakat karena keberadaannya dalam lingkungan tersebut. Kegiatan dalam masyarakat, media massa, teman bergaul, lingkungan tetangga merupakan hal-hal yang dapat mempengaruhi 
siswa sehingga perlu diusahakan lingkungan yang positif untuk mendukung belajar siswa. Dari berbagai faktor-faktor internal dan eksternal yang mempengaruhi prestasi belajar siswa maka peneliti mengkaji motivasi belajar dan metode pembelajaran.

Berkaitan dengan proses interaksi belajar mengajar ada beberapa faktor yang perlu diperhatikan antara lain adalah motivasi belajar dan metode pembelajaran. Motivasi belajar merupakan salah satu faktor internal yang cukup penting dalam proses belajar mengajar. Motivasi diperlukan untuk menumbuhkan minat terhadap pelajaran yang diajarkan oleh guru. Sedangkan metode pembelajaran juga salah satufaktor yang menentukan berhasil tidaknya proses belajar mengajar, dengan metode yang tepat secara otomatis akan mendukung pencapaian tujuan pembelajaran. Sehingga kedua faktoryang mempengaruhi prestasi belajar tersebut mempunyai andil yang cukup besar dalam kegiatan belajar. Belajar adalah salah satu kegiatan yang membutuhkan motivasi. Sayangnya motivasi ini tidak selalu timbul, sehingga terlihat ada siswa yang bersemangat, ada juga yang malas. Hal ini tercermin dari proses pembelajaran di MA Nurul Mutaqin. Siswa terlihat belum termotivasi untuk mengikuti pelajaran yang disampaikan oleh guru. Guru yang bersangkutan sudah berusaha membangkitkan motivasi siswa untuk mengikuti kegiatan belajar namun hasilnya belum maksimal. Guru banyak memberikan waktu ekstra untuk mengembangkan tugas yang diberikan dan memperluas materi belajar.

Selain itu guru juga menilai setiap tugas dan memberikan komentar secara tertulis. Metode yang digunakan guru dalam mengajar juga menentukan sikap siswa, sehingga siswa kurang bersemangat dalam mengikuti kegiatan belajar. Menggerakkan motivasi belajar dapat mendorong pencapaian prestasi belajar secara optimal. Walaupun siswa mempunyai bakat dan minat yang tinggi tetapi bila tidak disertai dengan motivasi belajar maka prestasi belajar tidak optimal begitu juga sebaliknya. Bisa juga siswa yang mempunyai intelegensi tinggi boleh jadi gagal karena kekurangan motivasi. Sehingga motivasi mempunyai peranan penting dalam kegiatan belajar karena motivasi adalah tenaga yang menggerakkan dan mengarahkan seseorang. Selain siswa unsur yang penting dalam kegiatan pembelajaran adalah guru. Di tangan gurulah terletak kemungkinan berhasil atau tidaknya penyampaian tujuan belajar.

Menurut pengalaman peneliti pada saat PPL (Praktik Pengalaman 
Lapangan) siswa cenderung kurang bersemangat pada saat belajar ekonomi. Semua itu terlihat dengan adanya sikap beberapa siswa yang kurang antusias dalam mengerjakan soal-soal ekonomi. Siswa kurang bersemangat untuk mengerjakan karena proses belajar mengajar terasa monoton. Metode pembelajaran yang diberikan kurang bervariasi sehingga timbul kebosanan pada siswa. Suasana kelas terlihat kurang hidup karena siswa menjadi pasif dalam mengikuti kegiatan belajar mengajar yang diberikan guru. Sehingga dibutuhkan strategi metode pembelajaran yang sesuai dengan situasi dan kondisi siswa. Pemilihan dan penggunaan metode yang tepat sesuai dengan tujuan kompetensi sangat diperlukan. Karena metode adalah cara yang digunakan oleh guru untuk mengadakan hubungan dengan siswa pada saat kegiatan belajar mengajar berlangsung.Untuk itu guru sebagai pengarah dan pembimbing tidak hanya pandai dalam memilih metode pembelajaran namun usaha guru-guru untuk mengoptimalkan komponen pembelajaran diperlukan dalam rangka meningkatkan prestasi belajar. Dimana ekonomi merupakan sebuah mata diklat yang membutuhkan kecermatan dan ketelitian sehingga metode yang digunakan harus sesuai agar mendapatkan hasil yang maksimal. Pengembangan metode yang tidak sesuai dengan tujuan pengajaran akan menjadi kendala untuk mencapai tujuan yang telah dirumuskan. Masalah yang timbul bagi siswa adalah bagaimana cara belajar yang efektif yaitu sesuai dengan teknik belajar yang standar dengan berlatih melatih otaknya untuk belajar terus dengan keteraturan, bagaimana melakukan penyesuaian dengan guru dan bagaimana menimbulkan kebiasaan teratur sehingga mencapai prestasi belajar yang optimal.

Dengan kurangnya semangat belajar dan rasa antusias siswa dalam mengerjakan soal-soal ekonomi, dikarenakan terlalu monoton metode yang digunakan seorang guru dalam proses belajar mengajar sehingga berdampak pada rendahnya nilai prestasi siswa yang masih banyak di bawah nilai Kriteria Ketuntasan Minimal (KKM) yang telah ditetapkan oleh pihak sekolahan.

Dari keterangan di atas peneliti mempunyai dugaan bahwa ada keterkaitan antara tinggi rendahnya motivasi belajar dan persepsi siswa tentang metode pembelajaran guru yang digunakan terhadap prestasi belajar. Berdasarkan pengamatan tersebut di atas peneliti tertarik untuk meneliti masalah ini ke dalam proposal skripsi dengan judul "Hubungan Motivasi Belajar dan Persepsi Siswa Tentang Metode Pembelajaran Guru Dengan Prestasi Belajar Ekonomi Siswa Kelas XI Semester I MA Nurul Mutaqin Penumangan Baru 
Tahun Pembelajaran 2011-2012".

Menurut Nasution (2000: 73) motivasi adalah segala daya yang mendorong seseorang untuk melakukan sesuatu. Dalam psikologi motivasi diartikan sebagai suatu kekuatan yang terdapat dalam diri manusia yang dapat mempengaruhi tingkah lakunya untuk melakukan kegiatan. Sedangkan menurut Abu Ahmadi dan Widodo Supriyono (2004: 83), motivasi sebagai faktor inner (batin) berfungsi menimbulkan, mendasari dan mengarahkan perbuatan belajar. "Dalam kegiatan belajar, motivasi dapat dikatakan sebagai keseluruhan daya penggerak di dalam diri siswa yang menimbulkan kegiatan belajar, yang menjamin kelangsungan kegiatan belajar dan yang memberikan arah kegiatan belajar sehingga tujuan yang dikehendaki oleh subyek belajar itu dapat tercapai" (Sardiman, 2006: 75).

Sedangkan menurut Mc. Donald yang dikutip oleh Sardiman (2006: 73) motivasi adalah perubahan energi dalam diri seseorang yang ditandai dengan munculnya "feeling" dan didahului dengan tanggapan terhadap adanya tujuan. Jadi dalam penelitian ini motivasi belajar diartikan sebagai dorongan yang ada dan timbul dalam diri siswa untuk belajar atau meningkatkan pengetahuan serta pemahaman ekonominya.

Sesuai dengan pengertian motivasi yang dijelaskan di atas, bahwa tidak perlu dipertanyakan lagi pentingnya motivasi bagi siswa dalam belajar. Di dalam kenyataan motivasi belajar tidak selalu timbul dalam diri siswa. Ada sebagian siswa yang mempunyai motivasi tinggi namun ada juga yang rendah motivasinya. Oleh karena itu seorang guru harus bisa membangkitkan motivasi yang terdapat dalam diri siswa agar dapat mencapai tujuan belajar. Bagi siswa yang sudah mempunyai motivasi, guru bertugas untuk meningkatkan motivasinya, jika guru dapat membangun motivasi siswa terhadap pelajaran yang diajarkan, diharapkan seterusnya siswa akan meminati pelajaran tersebut.

Persepsi adalah suatu anggapan yang ada pada pikiran manusia setelah menangkap suatu objek dengan panca indera. Menurut Slameto, "persepsi adalah proses yang menyangkut masuknya pesan atau informasi ke dalam otak manusia. Melalui persepsi manusia terus menerus mengadakan hubungan dengan lingkungannya (2003: 102).

"Belajar adalah suatu tingkah laku atau kegiatan dalam rangka mengembangkan diri, baik dalam aspek kognitif, psikomotorik, maupun sikap" (Darsono, 2000:64). Ketiga aspek tersebut merupakan satu kesatuan yang tidak terpisahkan. Oleh karena itu dalam kegiatan belajar mengajar harus berjalan secara efektif agar mampu 
mempengaruhi hasil belajar siswa. Prestasi belajar adalah hasil yang telah dicapai dari yang telah dilakukan, dikerjakan (Kamus Besar Bahasa Indonesia, 2003: 895). Prestasi belajar adalah bukti keberhasilan dari seseorang setelah memperoleh pengalaman belajar atau mempelajari sesuatu.

Menurut Tu'u (2004:75) prestasi belajar adalah penguasaan pengetahuan atau keterampilan yang dikembangkan oleh mata pelajaran, lazimnya ditunjukkan dengan nilai tes atau angka nilai yang diberikan oleh guru.

Tujuan dari Penelitian ini adalah untuk : (1) Untuk mengetahui Hubungan antara Motivasi Belajar Dengan Prestasi Pelajaran Ekonomi Siswa Kelas XI Semester I MA Nurul Mutaqin Tahun Pembelajaran 2011-2012. (2) Untuk mengetahui Hubungan antara Persepsi Siswa Tentang Metode Mengajar Guru Dengan Prestasi Pelajaran Ekonomi Siswa Kelas XI Semester I MA Nurul Mutaqin Tahun Pembelajaran 2011-2012. (3) Untuk mengetahui Hubungan antara Motivasi Belajar dan Persepsi Siswa Tentang Metode Mengajar Guru Dengan Prestasi Pelajaran Ekonomi Siswa Kelas XI Semester I MA Nurul Mutaqin Tahun Pembelajaran 2011-2012.

\section{METODE PENELITIAN}

Penelitian ini termasuk penelitian Asosiatif dengan menggunakan pendekatan ex-post facto. Dilihat dari timbulnya variabel, penelitian ini merupakan penelitian ex-post facto yaitu suatu penelitian yang dilakukan atas peristiwa yang telah terjadi untuk menemukan pengaruh atau hubungan variabel tertentu dengan variabel lainnya, tanpa adanya manipulasi langsung terhadap variabel independen. Dilihat dari tujuannya, penelitian ini merupakan penelitian korelasi, karena di dalam penelitian ini bermaksud untuk menemukan ada tidaknya hubungan antara motivasi belajar siswa dan persepsi siswa tentang metode mengajar guru dengan prestasi belajar ekonomi siswa kelas XI MA Nurul Mutaqin Penumangan Baru Tahun Pembelajaran 2011-2012. Variabel Independent (Variabel bebas) merupakan variabel stimulus atau variabel yang mempengaruhi variabel lain. Variabel bebas merupakan variabel yang faktornya diukur, dimanipulasi, atau dipilih oleh peneliti untuk menentukan hubungannya dengan suatu gejala yang diobservasi. Variabel bebas dalam penelitian ini adalah motivasi belajar siswa $\left(\mathrm{X}_{1}\right)$, dan persepsi siswa tentang metode mengajar guru $\left(\mathrm{X}_{2}\right)$ dan Prestasi Belajar (Y) sebagai variabel terikat.

Pengumpulan data yang digunakan pada penelitian ini menggunakan angket dan dokumentasi. Populasi dalam penelitian ini adalah kelas XI IPS yang berjumlah 39 siswa. Karen 
apopulasi hanya 31 siswa, maka sampelnya adalah 31siswa atau menggunakan sampel jenuh.

Teknikanalisa data yang digunakanantara lain: (1) Deskripsi data meliputi mean, median, dan modus, (2) uji prasyarat analisis meliputi uji validitas dan reliabilitas, (3) Pengujian Hipotesis. Pengujianh ipotesis untuk mengetahui ada tidaknya hubungan antar variabel menggunakan korelasi Product Moment, dan untuk mengetahui hubungan secara simultan, menggunakan korelasi Product Moment Multiple.

\section{HASIL DAN PEMBAHASAN}

\section{a. Uji Hipotesis Pertama}

Berdasarkan analisa data, dapat diketahui bahwa terdapat hubungan yang positif dan signifikan antara motivasi belajar siswa dengan prestasi belajar ekonomi siswa. Hasil perhitungan pengujian dengan SPSS menunjukkan dapat dilihat bahwa $r$ hitung $>r_{\text {tabel }}$ atau 0,886 $>0,355$ (table $\mathrm{r}$ dengan $\mathrm{dk}=31$ dan $\alpha=0.05)$ dan Sig. 2 tailed yaitu $0,000<0,05$ dengan demikian $\mathrm{H}_{\mathrm{o}}$ ditolak dan $\mathrm{H}_{\mathrm{a}}$ diterima. Kesimpulan Ada hubungan yang positif antara Motivasi Belajar $\left(\mathrm{X}_{1}\right)$ dengan Prestasi belajar ekonomi (Y).

\section{b. Uji Hipotesis Kedua}

Hasil penelitian menunjukkan bahwa terdapat hubungan yang positif dan signifikan antara Persepsi Siswa Tentang Metode Mengajar Guru dengan Prestasi Belajar
Ekonomi. Hal ini dibuktikan dari hasil analisis korelasi Product moment dengan menggunakan SPSS dapat dilihat bahwa $r$ hitung $>r$ tabel atau 0,670>0,355 (table $\mathrm{r}$ dengan $\mathrm{dk}=31$ dan $\alpha=0.05)$ dan Sig.2 tailed yaitu $0,000<0,05$ dengan demikian $\mathrm{H}_{\mathrm{o}}$ ditolak dan $\mathrm{H}_{\mathrm{a}}$ diterima.Kesimpulan Ada hubungan yang positif antara Persepsi Siswa Tentang Metode Mengajar Guru $\left(\mathrm{X}_{2}\right)$ dengan Prestasi belajar ekonomi (Y).

\section{c. Uji Hipotesis Ketiga}

Berdasarkan hasil analisis korelasi ganda antara Kebiasaan Belajar dan Persepsi Siswa Tentang Metode Mengajar Guru secara bersama-sama dengan Prestasi Belajar Ekonomi siswa yang menghasilkan koefisien korelasi ganda dengan menggunakan SPSS yaitu $R_{\text {hitung }}$ diperoleh sebesar 0,894 dan $R_{\text {tabel }}=0,355$ dengan demikian $R_{\text {hitung }}>R_{\text {tabel }}$ atau $0,894>0,355$. Kesimpulan Ada hubungan yang positif antara Motivasi Belajar $\left(\mathrm{X}_{1}\right)$ dan Persepsi Siswa Tentang Metode Mengajar Guru $\left(\mathrm{X}_{2}\right)$ dengan Prestasi belajar ekonomi (Y).

\section{PembahasanHasilPenelitian}

Berdasarkan data hasil penelitian yang telah dianalisis menunjukkan bahwa:

\section{KorelasiantaraMotivasi BelajardenganPrestasiBelajar Berdasarkan analisa data, dapat diketahui bahwa terdapat hubungan yang positif dan signifikan}


antara motivasi belajar siswa dengan prestasi belajar ekonomi siswa.

Menurut Abu Ahmadi dan Widodo Supriyono (2004: 83), motivasi sebagai faktor inner (batin) berfungsi menimbulkan, mendasari dan mengarahkan perbuatan belajar. "Dalam kegiatan belajar, motivasi dapat dikatakan sebagai keseluruhan daya penggerak di dalam diri siswa yang menimbulkan kegiatan belajar, yang menjamin kelangsungan kegiatan belajar dan yang memberikan arah kegiatan belajar sehingga tujuan yang dikehendaki oleh subyek belajar itu dapat tercapai" (Sardiman, 2006: 75).

Sedangkan menurut Sardiman (2006 :83) bahwa motivasi yang ada dalam diri seseorang memiliki ciriciri sebagai berikut:

1. Tekun menghadapi tugas (dapat bekerja terus menerus dalam waktu yang lama,tidak pernah berhenti sebelum selesai).

2. Ulet menghadapi kesulitan (tidak lekas putus asa).

3. Menunjukkan minat terhadap bermacam-macam masalah (minat untuk sukses).

4. Mempunyai orientasi ke masa depan.

5. Lebih senang bekerja mandiri.

6. Cepat bosan pada tugas-tugas yang rutin (hal-hal yang bersifat mekanis, berulang-ulang begitu saja, sehingga kurang kreatif).

7. Dapat mempertahankan pendapatnya (kalau sudah yakin akan sesuatu).
8. Tidak pernah mudah melepaskan hal yang sudah diyakini.

9. Senang mencari dan memecahkan masalah soal-soal. Apabila seseorang telah memiliki ciri-ciri motivasi di atas maka orang tersebut selalu memiliki motivasi yang cukup kuat.

Sesuai dengan pendapat Menurut Slameto (2003:54) faktorfaktor yang mempengaruhi prestasi belajar ada dua macam yaitu faktor internal dan faktor eksternal:

Faktor Internal adalah faktor yang ada dalam individu yang sedang belajar seperti:

a) Faktor Jasmaniah, meliputi : Faktor kesehatan proses belajar seseorang akan terganggu jika kesehatan orang terganggu, selain itu juga akan cepat lelah, kurang bersemangat, mudah pusing, mengantuk, kurang darah atau gangguan fungsi alat indera.

b) Cacat tubuh cacat tubuh ini dapat berupa buta, tuli, patah kaki dan patah tangan. Faktor Psikologis, meliputi : intelegensi siswa yang mempunyai tingkat intelegensi yang tinggi akan lebih berhasil daripada yang mempunyai tingkat intelegensi yang rendah. Siswa yang mempunyai intelegensi tinggi dapat berhasil dengan baik dalam belajarnya dikarenakan belajar dengan menerapkan metode belajar yangefisien. Sedangkan yang mempunyai intelegensi rendah perlu 
mendapatkan pendidikan khusus.

Perhatian-Perhatian menurut

Ghazali yang dikutip oleh

Slameto (2003:55) adalah

keaktifan jiwa yang dipertinggi, jiwa itu pun semata-mata tertuju kepada suatu obyek benda/hal atau sekumpulan obyek. Untuk dapat menjamin hasil belajar yang baik maka siswa harus mempunyai perhatian terhadap bahan yang dipelajarinya.

c) Minat adalah kecenderungan yang tetap untuk memperhatikan dan mengenang beberapa kegiatan. Minat besar pengaruhnya terhadap belajar. Bahan pelajaran yang menarik minat siswa, lebih mudah dipelajari dan disimpan karena minat menambah kegiatan belajar.

d) Bakat adalah kemampuan untuk belajar. Kemampuan itu baru akan terealisasi menjadi kecakapan yang nyata sesudah belajar atau berlatih.

e) Motivasi seseorang akan berhasil dalam belajarnya bila mempunyai penggerak atau pendorong untuk mencapai tujuan. Penggerak atau pendorong inilah yang disebut dengan motivasi.

f) Kematangan adalah suatu tingkat atau fase dalam pertumbuhan seseorang, di mana alat-alat tubuhnya sudah siap untuk melaksanakan kecakapan baru. Belajar akan berhasil bila anak sudah siap (matang).

g) Kesiapan adalah kesediaan untuk memberikan respon atau bereaksi. Kesiapan ini perlu diperhatikan dalam proses belajar mengajar karena jika siswa sudah memiliki kesiapan dalam belajar maka hasil belajarnya akan lebih baik. Faktor Kelelahan dibedakan menjadi dua macam yaitu kelelahan jasmani dan kelelahan rohani. Kelelahan jasmani terlihat dengan lemah lunglai, sedangkan kelelahan rohani terlihat dengan kelesuan dan kebosanan.

\section{Faktor Eksternal.}

a) Keadaan keluarga merupakan lingkungan utama dalam proses belajar. Keadaan yangada dalam keluarga mempunyai pengaruh yang besar dalam pencapaian prestasi belajar misalnya cara orang tua mendidik, relasi anggota keluarga, suasana rumah,keadaan ekonomi keluarga, pengertian orang tua.

b) Keadaan sekolah adalah lingkungan di mana siswa belajar secara sistematis. Kondisi ini meliputi metode mengajar, kurikulum, relasi guru dengan siswa, relasi siswa dengan siswa, disiplin sekolah, alat pelajaran, metode belajar dan fasilitas yang mendukung lainnya.

c) Keadaan masyarakat siswa akan mudah kena pengaruh lingkungan masyarakat karena keberadaannya dalam lingkungan tersebut. Kegiatan dalam masyarakat, media massa, teman bergaul, 
lingkungan tetangga merupakan hal-hal yang dapat mempengaruhi siswa sehingga perlu diusahakan lingkungan yang positif untuk mendukung belajar siswa. Dari berbagai faktor-faktor internal dan eksternal yang mempengaruhi prestasi belajar siswa maka peneliti mengkaji motivasi belajar dan metode pembelajaran.

Dari hasil penelitian dapat disimpulkan bahwa jika semakin tinggi Motivasi Belajar yang dimiliki siswa, maka Prestasi Belajar Ekonomi siswa akan semakin tinggi pula. Begitu pula sebaliknya, jika motivasi belajar siswa rendah atau dalam proses pembelajaran siswa mengalami malas maka prestasi belajar yang di dapat tidak akan maksimal atau prestasi belajar rendah.

\section{KorelasiantaraPersepsiSiswate ntangMetodeMengajar Guru denganPrestasiBelajar}

Hasil penelitian menunjukkan bahwa terdapat hubungan yang positif dan signifikan antara Persepsi Siswa Tentang Metode Mengajar Guru dengan Prestasi Belajar Ekonomi.

Hasil penelitian ini mendukung penelitian sebelumnya yang dilakukan $M$. Wahyu Untari (2009/2010) yang berjudul "Hubungan Antara Motivasi Belajar, Kebiasaan Belajar dan Persepsi Siswa Tentang Metode Mengajar
Guru dengan Prestasi Belajar Akuntansi Siswa Kelas XI Ilmu Sosial SMA Negeri 1 Cawas Klaten Tahun Ajaran 2009/2010", yang menyimpulkan bahwa terdapat hubungan yang positif dan signifikan antara Persepsi Siswa Tentang Metode Mengajar Guru dengan Prestasi Belajar.

Menurut Nana Sudjana (2005: 76), metode mengajar adalah "cara yang dipergunakan guru dalam mengadakan hubungan dengan siswa pada saat berlangsungnya pengajaran". Persepsi siswa tentang metode mengajar guru adalah proses penerimaan, penafsiran dan pemberian arti atau makna terhadap suatu objek atau informasi yang diterima melalui alat indera. Objek yang dimaksud adalah metode guru dalam menyampaikan materi pelajaran ekonomi. Dari hasil penelitian dapat disimpulkan bahwa jika Persepsi Siswa Tentang Metode Mengajar Guru yang dimiliki siswa semakin baik, maka Prestasi Belajar Ekonomi yang dicapai siswa juga akan semakin tinggi.

Sedangkan menurut Ahmadi (1997:53) yang dikutip Yatik Hidayanti mengemukakan syaratsyaratyang harus diperhatikan dalam penggunaan metode mengajar adalah:

1. Metode mengajar harus dapat membangkitkan motif, minat atau gairah belajar siswa. 
2. Metode mengajar harus dapat menjamin perkembangan kegiatan kepribadian siswa.

3. Metode mengajar harus dapat memberikan kesempatan bagi siswa untuk mewujudkan hasil karya.

4. Metode mengajar harus dapat merangsang keinginan siswa untuk belajar lebih lanjut, melakukan eksplorasi dan inovasi (pembaharuan).

5. Metode mengajar harus dapat mendidik murid dalam teknik belajar sendiri dancara memperoleh pengetahuan melalui usaha pribadi.

6. Metode mengajar harus dapat meniadakan penyajian yang bersifat verbalitas dan menggantinya dengan pengalaman atau situasi yang nyata dan bertujuan.

7. Metode mengajar harus dapat menanamkan dan mengembangkan nilai dan sikap-sikap utama yang diharapkan dalam kebiasaan cara bekerja yang baik dalam kehidupan sehari-hari. Guru sebagai salah satu sumber belajar berkewajiban menyediakan lingkungan belajar yang kreatif bagi kegiatan belajar anak didik di kelas. Salah satu kegiatan yang harus dilakukan adalah melakukan penentuan dan pemilihan metode. Suatu metode yang digunakan oleh guru untuk mengajar harus benar-benar dikuasai. Sehingga pada saat penggunaannya dapat menciptakan suasana interaksi edukatif.

Hal ini sesuai dengan kajian teori dan kerangka berfikir pada penelitian ini di mana siswa yang mempunyai persepsi positif akan cenderung menerima dan menyukai metode mengajar guru sehingga terlihat antusias dalam mengikuti pelajaran. Sebaliknya, siswa yang mempunyai persepsi negatif akan menyebabkan siswa kurang tertarik terhadap materi pelajaran yang disampaikan.

\section{Korelasi antara Motivasi Belajardan Persepsi Siswa tentang Metode Mengajar Guru dengan Prestasi Belajar} Hipotesis penelitian yang ketiga menyatakan "Terdapat hubungan yang positif antara Motivasi Belajar, dan Persepsi Siswa Tentang Metode Mengajar Guru dengan Prestasi Belajar Ekonomi Siswa Kelas XI MA Nurul Mutaqin Peumangan Baru Kabupaten Tulang Bawang Barat Tahun Pembelajaran 2011-2012".

Sedangkan Menurut Slameto (Belajar dan Faktor-faktor yang Mempengaruhinya 2003: 54-72) ada dua faktor yang mempengaruhi belajar yaitu:

1) Faktor Intern

Yaitu faktor yang ada dalam diri individu yang sedang belajar. 
Faktorintern meliputi tiga faktor yaitu :

a) Faktor jasmaniah, antara lain faktor kesehatan dan cacat tubuh

b) Faktor Psikologis, antara lain intelegensi, perhatian,minat, bakat, motif, kematangan, kesiapan.

c) Faktor kelelahan, antara lain kelelahan jasmani dan kelelahan rohani (bersifat psikis). Kelelahan ini dapat dihilangkan dengan cara tidur, istirahat, rekreasi danibadah yang teratur, olahraga secara teratur.

\section{2) Faktor Ekstern}

Yaitu faktor yang ada di luar individu. Faktor ekstern dapat dikelompokkan menjadi tiga faktor yaitu: faktor keluarga, sekolah, masyarakat.

a) Faktor Keluarga terdiri atas cara orang tua mendidik,relasi antar anggota keluarga, suasana rumah, keadaanekonomi keluarga, perhatian orang tua, latar belakang kebudayaan.

b) Faktor Sekolah terdiri atas metode mengajar, kurikulum, relasi guru dengan siswa, relasi siswa dengan siswa, disiplin sekolah, alat pelajaran, waktus ekolah, metode belajar.

c) Faktor Masyarakat terdiri atas kegiatan siswa dalam masyarakat, media massa, teman bergaul, bentuk kehidupan masyarakat.

Sedangkan menurut Muhibbin Syah (Psikologi Pendidikan Dengan Pendekatan Baru 2003: 132) faktor-faktor yang mempengaruhi prestasi belajar dapat dikelompokkan menjadi tiga macam, yakni :

1) Faktor internal (faktor dari dalam siswa)

2) Faktor eksternal (faktor dari luar diri siswa), yakni: kondisi lingkungan di sekitar siswa, dan

3) Faktor pendekatan belajar yakni: jenis upaya belajar siswa yang meliputi strategi dan metode yang digunakan untuk melakukan kegiatan pembelajaran materi-materi pelajaran.

Dari pendapat beberapa ahli tersebut diatas, apabila faktor intern dan faktor ekstern baik, maka prestasi belajar yang akan diperoleh oleh siswa akan maksimal.

\section{SIMPULAN}

Berdasarkananalisa data yang diperoleh, maka dapat disimpulkan sebagai berikut:

1. Terdapat hubungan positif dan signifikan antara variabel Motivasi Belajar Siswa dengan Prestasi Belajar Ekonomi Siswa Kelas XI MA Nurul Mutaqin Penumangan Baru Kabupaten Tulang Bawang Barat Tahun Pembelajaran 2011-2012. 
2. Terdapat hubungan positif dan signifikan antara variabel Persepsi Siswa Tentang Metode Mengajar Guru Dengan Prestasi Belajar Ekonomi Siswa Kelas XI MA Nurul Mutaqin Penumangan Baru Kabupaten Tulang Bawang Barat Tahun Pembelajaran 20112012. Hal ini mengandung implikasi pentingnya persepsi positif dari seorang siswa terhadap metode mengajar guru, sehingga seorang guru diharapkan mampu menanamkan persepsi yang baik tentang metode yang digunakannya untuk mengajar. Penanaman persepsi yang baik di dalam diri siswa akan berhubungan dengan kesenangan seorang siswa dalam mengikuti pelajaran dengan sungguh-sungguh, mendalami materi dan melaksanakan kewajibannya untuk belajar, dengan demikian akan mampu meningkatkan prestasi belajar ekonomi siswa.

3. Terdapat hubungan positif dan signifikan antara variabel Motivasi Belajar Siswa dan Persepsi Siswa Tentang Metode Mengajar Guru Dengan Prestasi Belajar Ekonomi Siswa Kelas XI MA Nurul Mutaqin Penumangan Baru Kabupaten Tulang Bawang Barat Tahun Pembelajaran 20112012. Hal ini mengandung implikasi bahwa Seorang siswa juga diharapkan mempunyai motivasi belajar yang baik.
Selain itu guru juga diharapkan dapat menerapkan metode yang baik dalam mengajar sehingga tertanam persepsi yang baik atau positif di dalam diri siswa mengenai metode mengajar yang digunakan oleh guru. Dengan demikian siswa akan terpacu untuk mendapatkan prestasi belajar yang lebih baik lagi.

\section{DAFTAR PUSTAKA}

Slamento, (2003). Belajar dan Faktor-Faktor yang Mempengaruhinya. Jakarta : Rineka Cipta

Nana Sudjana. (2005). Dasar-Dasar Proses Belajar Mengajar. Bandung : SinarBaru Algensindo.

Syah, Muhibbin. (2003). Psikologi Pendidikan. Jakarta : LOGOS Nasution. 2000. Berbagai Pendekatan dalam Proses Belajar dan Mengajar. Jakarta:Bumi Aksara.

Tu'u, Tulus. 2004.Peran Disiplin Pada Perilaku dan Prestasi Siswa. Jakarta:Grasindo.

Sardiman, AM. 2006. Interaksi dan Motivasi Belajar Mengajar.Jakarta: PT. RajaGrafindo Persada.

M. Wahyu Untari (2011). Hubungan Antara Motivasi Belajar, Kebiasaan Belajar, dan Persepsi Siswa Tentang Metode Mengajar Guru PrestasiBelajar Ekonomi Siswa Kelas XI IPS Tahun Ajaran 2009/2010. Sekripsi FISE UNY. 